\title{
DIGITALIZATION IN INSURANCE COMPANIES
}

\author{
Krzysztof ŁYSKAWA(D) ${ }^{1}$, Arleta KĘDRA (D) ${ }^{2}$, Lyubov KLAPKIV(D) ${ }^{*}$, Jurij KLAPKIV (D) ${ }^{4}$ \\ ${ }^{I}$ Department of Insurance, Faculty of Economics, Poznan University of Economics and Business, \\ al. Niepodleglości 10, 61-875, Poznań, Poland \\ ${ }^{2}$ Department of Statistics and Econometrics, Maria Curie-Skłodowska University in Lublin, \\ pl. M.Curie-Sklodowskiej 5, 20-031 Lublin, Poland \\ ${ }^{3}$ Department of Insurance, Maria Curie-Sktodowska University in Lublin, \\ pl. M.Curie-Skłodowskiej 5, 20-031 Lublin, Poland \\ ${ }^{4}$ Department of Insurance, University of Łódź, Rewolucji 1905 r. 41/43, 90-241 Łódź, Poland \\ "E-mail: liuba.klapkiv@poczta.umcs.lublin.pl
}

\begin{abstract}
Purpose - the main idea of the article was to characterize the process of digitalization in insurance companies through the implementation of information and communication technologies (ICT). This research examined the relationship between the expenses for information technologies of selected insurance companies and the results of their activity.
\end{abstract}

Research methodology - the research had empirical character and was based on the analysis of two groups of indicators: digitalization and insurance. The first group characterizes the level of insurance companies' investments in ICT, and the second - the results of insurance activity. Data were collected from notes to financial statements of top 4 European insurance groups. The results have been received based on correlation analysis.

Findings - the results of the research showed that there is a different tendency in the raising of ICT investments and the values of gross premiums, claims, and expenses. This result deals with the important question in insurance if the higher invests in technologies could be a factor of insurers' effectiveness.

Research limitations - most important limitation relates to the lack of complete data about information and communication technologies in insurers. It is closely connected with some ambiguity in defining modern information technologies.

Practical implications - the results of the research could be used in the decision-making process in practice or future research.

Originality/Value - in the research the possibility to combine analysis and comparison of selected parameters of digitalization based on financial statements of insurance companies was described.

Keywords: digitalization, insurer, software, premium, claim, expenditure.

JEL Classification: G22, O33.

Conference topic: Digitalization of Business Processes: Trends, Challenges, Solutions.

\section{Introduction}

Digitalization is one of the most actual topics in the insurance sector both from the theoretical (Eling \& Lehmann, 2018) and practical point of view (International Association of Insurance Supervisors, 2018; Mizgier, Kocsis, \& Wagner, 2018). There is a lot of framework about this phenomenon in general, as well as in the context of the financial market. Insurance also becomes an area of technologies introduction. The global investments in insurance digitalization rise fast and it could indicate strong attention to digitalization among insurance companies. We named the most important global trends that are helpful in showing the importance of our research and formulating our hypotheses. So, several statements can be made:

- digital transformation has a strong influence on the insurance value chain (Eling \& Lehmann, 2018; Stoeckli, Dremel \& Uebernickel, 2018);

- digitalization impacts on processes of distribution, underwriting, pricing and claims (International Association of Insurance Supervisors, 2018); 
- insurance companies are looking for new opportunities in how information technologies could be used (e.g. Omni-channels, big data analytics, Internet of Thing, telematics, voice biometrics and analysis, drones and satellites, etc.) (Bohnert, Fritzsche, \& Gregor, 2019).

There is no doubt about the development of information technologies' supply that could have a valuable effect on insurance companies: global Big Data market volume raised from \$ 7,6 bln in 2012 to \$ 35 bln; the size of the public cloud computing service market increased from $\$ 58,6$ bln in 2008 to $\$ 145$ bln in 2017; the global IoT market raised from \$ 182,2 bln in 2009 to $\$ 1$ 130,3 bln in 2017 (Statista, 2019a). According to the global statistics, the value of capital invested in insurance tech companies from 2012 to 2017 increased from $\$ 326$ mln to $\$ 2,134$ mln, the number of deals in this period increased from 86 to 247 (Statista, 2019b). So, there are favorable circumstances from the supply side for digitalization of insurance company (taking into consideration legislate restrictions).

The main problem of the research lies in the lack of substantiated approaches to the analysis of digitalization at the level of insurance companies. There is no unified parameter of digitalization in insurance. Each researcher or practitioner choose his or her own criteria for digitalization.

The main goal of the research is to characterize the relationship between IT expenses as an indicator of digitalization and the activity of insurers. In this article, we characterized the process of digitalization in insurance companies in the meaning of information and communication technologies' (ICT) implementation.

The tasks of the research:

- to explain the nature of digitalization in insurance and to show the place of ICT in this process;

- to argue the possibility of using the financial statement data (IT expenses and software gross value) for analysis of digital activity in the insurance company;

- to show the relationship between selected parameters of digitalization (IT expenses and software value) in insurance and their activity (growth of premium and acquisition costs).

In compliance with global trends that were accepted, in the article we analyzed the following hypothesis:

- the insurance companies increase their expenses for software and information technologies if their insurance premiums rise;

- the insurance companies increase their expenses for software and information technologies if their acquisition expenses rise;

- the insurance companies start to spend more money on software and IT.

Methods. The analysis of aforementioned questions were conducted with the use of econometric tools - correlation examinations on the basis of the heat map, constructed with the application of Gretl software, and time trends models of financial data from the selected companies.

\section{The nature of digitalization in insurance}

The process of digitalization is closely related to using information and communication technologies in the insurance sector. There are widely used the expression "digitalization of insurance" (Stöckli, Uebernickel, \& Brenner, 2016; Nicoletti, 2016; Schmidt, Möhring, Bär, \& Zimmermann, 2017; Cappiello, 2018) that means the implementation of ITC into insurance. Digital transformation in the insurance industry was described through the approach - Digital Transformation Framework in the cases of selected German insurers (Wiesböc, Li, Matt, Hess, \& Richter, 2017).

Most of the definitions describe digitalization as:

- taking processes, content or objects that used to be primarily (or entirely) physical or analog and transforming them to be primarily (or entirely) digital (Fichman, Dos Santos, \& Zheng, 2014);

- the expression of information in strings of 0 and 1 called binary or digital strings (Vogelsang, 2010).

Some of the more comprehensive and involve both these items. Digitalization is characterized by some features: volatility, uncertainty, complexity, ambiguity (Bennett \& Lemoine, 2014). Coletti (2018) also links the actual raising digitalization process in the insurance sector with technological development, profit-reducing and needs of cost-cutting. Cappiello (2018) shows the impact of digitalization on the insurance industry through the use of Big Data, artificial intelligence/cognitive computing, predictive modeling, wearable devices, telematics, and the IoT in the creation of value chain. The nature of IT in insurance was also showed through Green IT (Essvale Corporation Limited, 2009).

We suggest that digitalization means the introduction of Information and Communication Technologies (ICT) into insurance business for the purpose of cost cutting and income increase.

But as we have shown, the majority of modern research shows the process of digitalization of insurance companies based on ICT. Illustration 1 shows the logic of our research's subject: digitalization development in the insurance company according to the level and kind of technology that is integrated into the company's activity.

A smaller unit of the digitalization is software. Other technological staff could also be used in insurance activity. The software is a kind of information and communication technology. But in the official report companies don't illustrate such a comprehensive parameter as ICT. Information and communication technology includes computers, software, electronic components, and telecommunication equipment (Mansell, Avgerou, Silverstone, \& Quah, 2007). The whole process of introduction and using ICT is called digitalization. 


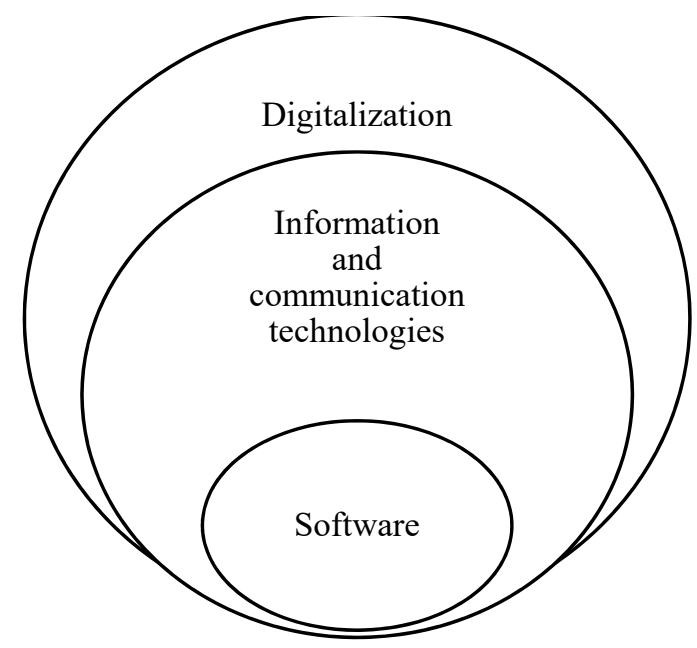

Figure 1. The logic of development of digitalization in insurance companies (source: own collaboration)

The main aim of Information and communication technologies in the insurance market is to create and use the knowledge and exchange the information (Manning, Stephenson, \& Todd, 2007; Engel, 1985). The role of ICT has been changing: previously ICT was the instrument for data processing, but after the implementation of Big Data in the economy, it has become the instrument for creating new types of data. The insurance industry is totally dependent on the ability to convert raw data into intelligence - intelligence about customers, markets, competitors, and business environment (Sumathi \& Sivanandam, 2006). Modern insurance business looks for opportunities to reduce the asymmetry of information under the condition of the rising cost of risks. So, insurers are looking for new knowledge about the probability of the risks. Heeks (2017) explains the relationship between knowledge, information, and data as data is processed into information is assimilated into knowledge; knowledge explains information and processes data. Forman and Gron (2011) showed a connection between vertical integration in distribution construction of insurance company and the adoption of new technologies (Internet). Some aspects of IT integration into financial institution were discussed in the context of the connection between banking and IT (Marinč, 2013).

Study of the link between life insurer IT expenditure and the efficiency of its activity was based on financial data in the research made by Francalanci and Galal (1998). A few studies show the linkage between the IT budget (as a part of intangible assets) and the financial condition of companies from different points of view: between investment in computers and company's market value (Brynjolfsson, Hitt, \& Yang, 2002). Harris and Katz (1991) compared the rate of IT expense and the total operating expense among large and small insurers, and titled it as an indicator of "IT intensity".

To assess the link between the value of insurance premiums and IT expenses in the insurance company Harris and Katz (1991) used time-lagged regression, because of the assumption that the change in the amount of IT expenditure is the result of the insurance premium growths in previous periods. To confirm this hypothesis, six different timelagged models were used: with a one-year lag, two-year lag, and three-year lag. Currently, there is a lack of knowledge in the literature about empirical methods for studying the influence and relations between IT and insurance company's growth.

\section{The methodology of the research}

The research has empirical character and was based on the analysis of two groups of indicators: digitalization and insurance. The first group characterizes the level of insurance companies' ICT (software) expenses, and the second the results of insurance activity: gross written premiums and acquisition expenses. Data was collected from notes to financial statements of selected four biggest European insurance groups. The results have been received based on correlation analysis. The period that has been analyzed involves 10 years (from 2008 to 2017).

We reflected the possibility of using the parameters from Consolidated Financial Statements. In accordance with International Financial Reporting Standards (in the European Union), patented technology, computer software, databases are reflected in Intangible assets (IAS 38). However, this type of asset includes a wider list of non-monetary assets, such as trademarks, trade dress, video, and audiovisual materials, marketing rights and so on. In the notes of financial statements, the insurance company could show the value of software: separately acquired and internally developed. In addition, in the notes to the consolidated financial statements, the insurer could show the expenses for software. But it should be noted that insurance companies reflect only that software that will lead to future economic benefits. Software that does not meet the criteria: generate probable future economic benefits and measure costs reliably, will be reflected as a loss. 
Besides patented technology, computer software, databases, the insurance company may also participate in a joint venture. Funds related to such participation are shown in notes to consolidated financial statement (IAS 31). It should be noted that the joint venture includes various types of investments, such as real estate, healthcare, a specific way of client contacts. Joint venture embraces investment in young companies (often Start-up), that deals with the development and implementation of technology in the insurance business.

In the research, data was used from AXA Group (France), Zurich Insurance Group (Switzerland), CNP Assurances (2019) (France) and Talanx Group (Germany). The main criterion was the value of a gross written premium, but the number of observed items were limited because just part of companies opens the information about. All these groups belong to top 10 European insurance companies according to criteria of gross writing premiums. Consolidated financial statements of the Groups have been prepared in accordance with International Financial Reporting Standards (IFRS). The choice of companies was limited by the amount of information in the annual reports. There are some differences in financial statement approaches. We tried to eliminate such things and chose companies with equal approaches.

Table 1. Selected indicators for analysis (source: own collaboration)

\begin{tabular}{|c|l|l|}
\hline Indicator & \multicolumn{1}{|c|}{ Explanation } & \multicolumn{1}{|c|}{ Reference } \\
\hline Software value & $\begin{array}{l}\text { Software value is an indicator that was used to de- } \\
\text { scribe the digitalization process and the processes of } \\
\text { using the technologies }\end{array}$ & $\begin{array}{l}\text { Strålin, Gnanasambandam, Andén, Comella- } \\
\text { Dorda, \& Burkacky, 2016; Weingarth, Ha- } \\
\text { genschulte, Schmidt, \& Balser, 2019 }\end{array}$ \\
\hline $\begin{array}{c}\text { Information tech- } \\
\text { nologies expenses } \\
\text { / expenditures }\end{array}$ & $\begin{array}{l}\text { Were used to show the indicator of technologies im- } \\
\text { plemented in the companies and it influences on com- } \\
\text { pany's activity (profitability, effectiveness, etc.) }\end{array}$ & $\begin{array}{l}\text { Shin, 2001; Navarrete \& Pick, 2002; Mithas, } \\
\text { Tafti, Bardhan, \& Goh, 2012; Sidorova, Torres, } \\
\text { \& Al Beayeyz, 2015 }\end{array}$ \\
\hline $\begin{array}{c}\text { Gross written pre- } \\
\text { mium }\end{array}$ & $\begin{array}{l}\text { Showed the development of insurance company } \\
\text { or industry }\end{array}$ & $\begin{array}{l}\text { Kramarić, Bach, Dumičić, Žmuk, \& Žaja, 2018; } \\
\text { Tien \& Yang, 2014; Berry-Stölzle, Hoyt, \& } \\
\text { Wende, 2010 }\end{array}$ \\
\hline Acquisition costs & Expenditure on finding a new contract & $\begin{array}{l}\text { Trigo-Gamarra \& Growitsch, 2010; } \\
\text { Gatzert (2019) }\end{array}$ \\
\hline
\end{tabular}

For analysis were chosen following indicators (see Table 1).

Software gross value. The value of software is included in intangible assets and developed for internal use for which direct costs are capitalized and amortized on a straight-line basis over the assets' estimated useful lives (AXA, 2019). Costs associated with research and maintenance of internally-developed computer software are expensed as incurred. Costs incurred during the development phase of computer software are capitalized when the following recognition criteria are met (International Accounting Standards [IAS], 2014):

- it is technically feasible to complete the software product so that it will be available for use;

- management intends to complete and there is an ability to use or sell the software product;

- the software is expected to generate future economic benefits;

- sufficient resources are available to complete the development of the software;

- expenditures can be reliably measured.

Software under development is tested for impairment annually. Acquired computer software licenses are capitalized based on the costs incurred to acquire and bring specific software into use (Zurich, 2019).

The useful lives of computer software licenses and capitalized internal software development costs often range from three to five years. In limited circumstances, capitalized software development costs may be amortized over a period of up to ten years, considering the effects of obsolescence, technology, innovation, competition andothereconomic, and legal factors.

Companies represent breakdown for software value like so: accumulated amortization, accumulated impairment, and software net value.

IT expenses includes compensation for IT professionals and expenses related to the construction and maintenance of enterprise-wide systems and services.

Gross written premiums. Gross written premiums correspond to the number of premiums written by insurance and reinsurance companies on business incepted in the year with respect to both insurance contracts and investment contracts with discretionary participating features, net of cancellations and gross of reinsurance ceded.

Acquisition costs include commissions and general expenses allocated to new business. It includes all selling, distribution and administrative costs incurred for the acquisition of new contracts.

The method used for analysis includes an examination of the linear correlation between specific variables in particular companies and its presentation on a heat map. The next step will include econometric analysis of linear time trends for financial variables in the selected companies, applied according to Ordinary Least Squares. If it occurs that the trend is not linear, a squared (or cubed) time variable will be used. The assumptions of OLS will be verified with 
the application of White's test for heteroscedasticity, Remsey's RESET test for linearity, and Durbin-Watson's test for autocorrelation (AR1) with the significance level of $1 \%$.

\section{Findings and discussion}

Figure 2 showed the dynamics of changes in values of selected parameters over the period 2008-2017 for all companies. Each company has its own dynamics off changes in grow written premiums, software gross value, IT expenses and acquisition expenses. The key finding of this analysis give us conclusions (based on Figure 2):

1. The gross value premiums in AXA Group raised for from 84.66 to 92.05 million euro. The value of software has doubled over this period (from 1.87 to 3.13 million euro) as IT expenses (from 0.78 to 1.36 million euro). But acquisition expenses did not raise basically (from 10.14 to 12.02 million euro).

2. The gross value premiums in Zurich Group decreased by $14 \%$ (from 51.89 to 45.05 million euro). The value of software increased over this period for $206 \%$ (from 1.56 to 4.78 million euro). The IT expenses raised for $71 \%$ from 0.81 to 1.39 million euro. But acquisition expenses did not raise basically (from 8.28 to 9.09 million euro).

3. The gross value premiums in CNP Group raised from 28.27 to 32.46 million euro (14\%). The value of software has raised over this period for $126 \%$ from 0.19 to 0.43 million euro. At the same time, acquisition expenses did not raise basically (for 34\%).

4. The gross value premiums in the Talanx Group raised for about $74 \%$, from 19.00 to 33.06 million euro. The value of software has raised less than for $43 \%$ over this period from 0.39 to 0.56 million euro. At the same time, acquisition expenses raised for $76 \%$.

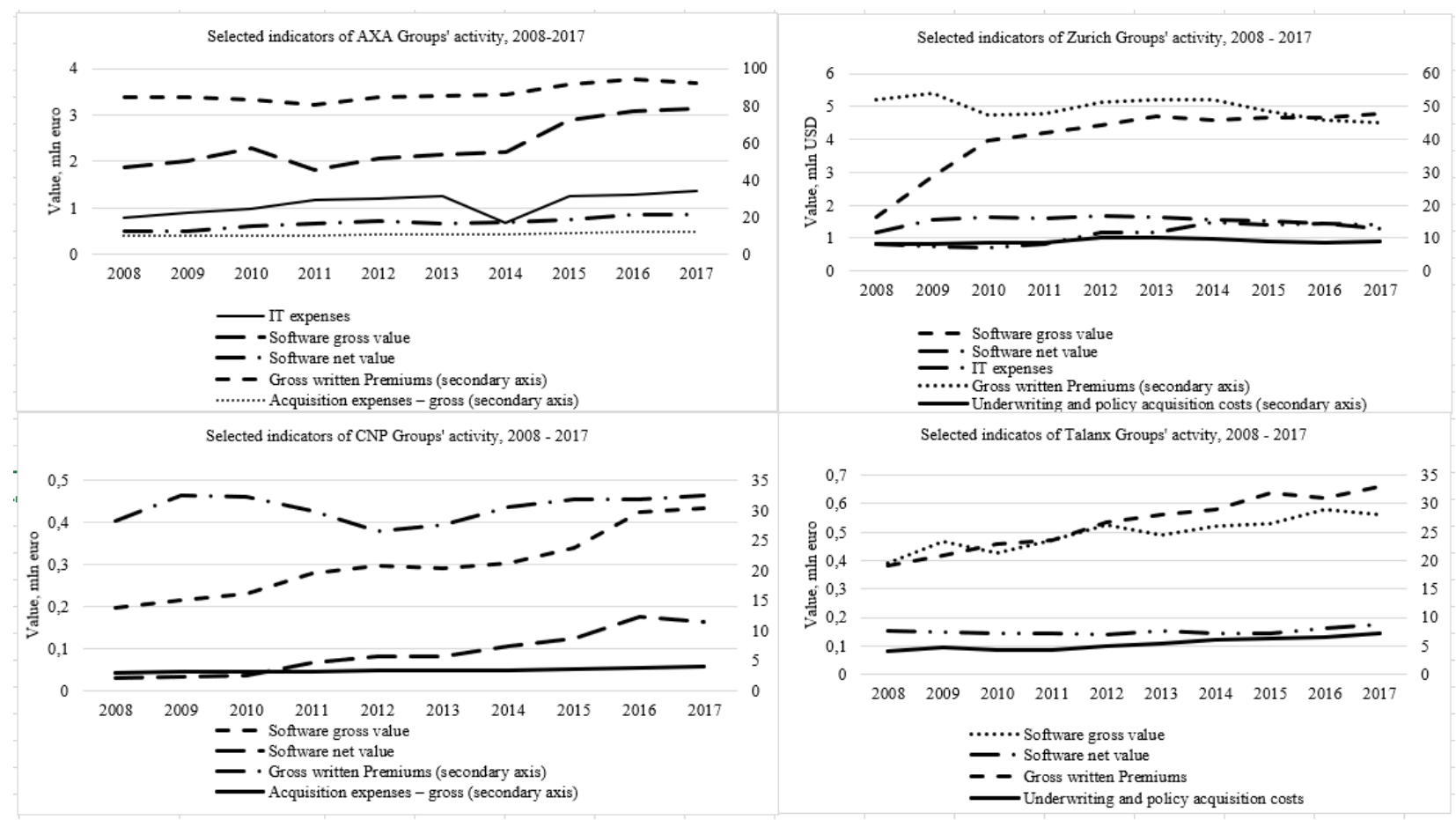

Figure 2. Dynamics of selected companies' indicators, 2008-2017 (source: own collaboration based on AXA Group, 2019; Zurich Group, 2019; Talanx, 2019; CNP, 2019)

Figure 3 presents correlation matrices between gross value, the value of gross written premiums and acquisition expenses of the analyzed companies. In AXA a strong positive correlation was found both between the gross value and gross written premiums (Pearson coefficient of correlation equaling 0.9419) and between gross value and acquisition expenses (Pearson coefficient of correlation equals 0.9397). In the case of CNP, a different situation was discovered there is a strong positive (almost perfect) correlation between gross value and acquisition expenses (Pearson coefficient of correlation at the level of 0.9726 ) but the relation between gross value and gross written premiums appears to be positive but insignificant (Pearson coefficient of correlation equaling 0.2853 ) while correlation between gross written premiums and acquisition expenses is positive but medium (Pearson coefficient of correlation equaling 0.4079). Talanx presents similar results as AXA - there is a strong positive correlation between gross value of the company and gross written premiums (Pearson coefficient of correlation equals 0.9032), between gross value and acquisition expenses (Pearson coefficient of correlation at the level of 0.8629), and between gross written premiums and acquisition expenses (Pearson coefficient of correlation equaling 0.9278). A correlation matrix, discordant to the previously discussed companies, was constructed for Zurich company. In this case, a medium positive correlation between gross 
value and acquisition expenses was revealed (Pearson coefficient of correlation equaling 0.6035) while there was a very low degree of correlation between gross written premiums and acquisition expenses (Pearson coefficient of correlation at the level of 0.2247 ). What was surprising, there is a medium negative correlation between the gross value of the company Zurich and its gross written premiums (Pearson coefficient of correlation equalling -0.4859 ). This indicates that if the gross written premiums increase by 1 , the gross value of the company decreases by ca. 0.5 .

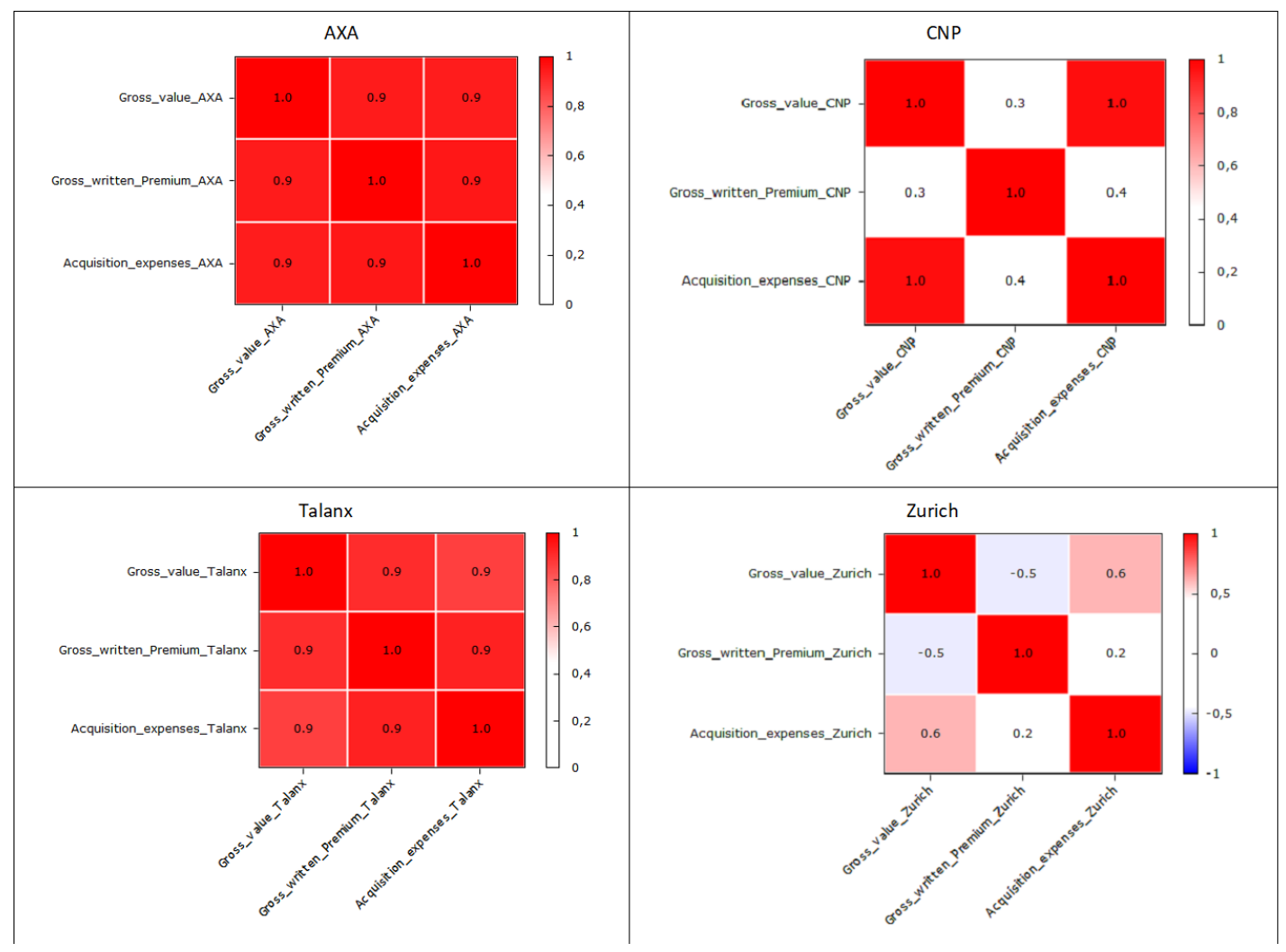

Figure 3. Correlation matrices of analyzed insurance companies (source: own research based on Consolidated Financial Statements (Gretl CC))

Table 2 presents selected summary statistics for analyzed variables. Mean and the standard deviation was calculated to determine the coefficient of variation. This coefficient indicates how big a share in the mean value has a standard deviation. The bigger the coefficient of variation, the bigger variability (more differentiated values) of the variable. The last column presents average change over the analyzed period (measured as a geometrical mean of chain indexes). It is an indicator that shows how the variable changed in subsequent years, i.e. how this variable changed in each year (on average). Negative numbers indicate a decrease, positive numbers indicate an increase. In case of Zurich (were a negative correlation between variables was revealed) a significant increase in gross value was discovered (by $11.33 \%$ in each year - on average), while there was a decrease in gross written premiums (by $1.4 \%$ on each year - on average).

An econometric analysis of given variables was conducted (Table 3). The impact of time was examined for all the analyzed variables with the application of line trend, where insurance variables were used as dependent variables while the time was used as a regressor. In each case, the significance of coefficients was analyzed using $10 \%$ significance level. In four cases (marked with asterisks) it occurred that that time does not play a crucial role and does not affect the changes in variables, for these models verification was done, but they were not taken into account. For them, further analysis of time trends was conducted - time squared and cubed were used as regressors. If they appeared to be significant (which was true for the verified models, apart from one case - gross written premiums in CNP) it was proven that the development of analyzed variables is not linear - they fluctuate not necessarily according to time. In all the other cases the linear changes over time are significant, although sometimes they do not cause great increases or decreases. In each case, the value of coefficient shows how the value of the variable will increase (or decrease, if the coefficient is negative) in a subsequent year. For all the above-given models were estimated with the use of the Ordinary Least Squares method, which indicates that the error term has particular attributes homoscedasticity or no serial correlation. Therefore, tests for heteroscedasticity (White's test), linearity (Ramsey's RESET test) and autocorrelation (Durbin-Watson test) were made (Table 3). Their interpretation was applied according to the econometric theory (for more on heteroscedasticity see (Wooldridge, 2012), on autocorrelation, on functional form misspecification), i.e. if the significance level was higher than the $\mathrm{p}$-value we failed to reject the null hypothesis. The significance 
level of $1 \%$ was applied. If the null hypothesis (in all the cases null hypothesis should be failed to be rejected to state that these negative phenomena are not present in analyzed models) was rejected, another model was applied - with time squared or time cubed (if there were more than one independent variables, their order is the same as their power first time, then time squared and/or time cubed). The most significant impact of time was revealed in case of Zurich time has a positive influence on the gross value of Zurich (it increases over the time), while time squared has a negative impact on this value, and time cubed has also a positive influence on it. This indicates that the gross value of the Zurich company is not linear and fluctuates over time. In case of gross written premiums in CNP, none of the fitted models appeared to be correct, as the coefficients are insignificant (both for models with time squared and time cubed). The least impact of time can be observed on acquisition costs in Talanx (only 0.03 increase in each year and 0.001 for time squared). In this case, as we rejected the null hypothesis in Durbin-Watson test (there was a serial correlation) and in RESET test (the functional form was not linear) a Prais-Winsten (Wooldridge, 2012) estimator was applied. Although it was correct ( $p$-value in Jarque-Berra test equalling 0.475 ), an analysis of time trend was preserved.

Table 2. Summary statistics of selected parameters (source: own study based on Consolidated Financial Statements (Gretl CC))

\begin{tabular}{|c|c|c|c|c|}
\hline Variable & Mean & Standard deviation & $\begin{array}{c}\text { The coefficient of } \\
\text { variation, } \%\end{array}$ & $\begin{array}{c}\text { Average change over } \\
\text { the period, } \%\end{array}$ \\
\hline Gross value AXA & 2.347 & 0.494 & 21.05 & 5.28 \\
\hline Net Value AXA & 0.684 & 0.126 & 18.44 & 5.81 \\
\hline Gross written Premiums AXA & 86.761 & 4.390 & 5.06 & 0.84 \\
\hline Acquisition expenses AXA & 10.881 & 0.829 & 7.62 & 1.71 \\
\hline Gross value Zurich & 4.052 & 1.024 & 25.27 & 11.33 \\
\hline Net Value Zurich & 1.506 & 0.166 & 11.05 & -1.40 \\
\hline Gross written Premiums Zurich & 49.586 & 2.985 & 6.02 & 0.93 \\
\hline Acquisitions expenses Zurich & 9.030 & 0.703 & 7.78 & 8.33 \\
\hline Gross value CNP & 0.300 & 0.081 & 27.00 & 18.74 \\
\hline Net Value CNP & 0.089 & 0.052 & 58.69 & 1.39 \\
\hline Gross written Premiums CNP & 30.388 & 2.209 & 7.27 & 2.95 \\
\hline Acquisition expenses CNP & 3.363 & 0.331 & 9.85 & 3.60 \\
\hline Gross value Talanx & 0.497 & 0.058 & 11.77 & 1.48 \\
\hline Net Value Talanx & 0.151 & 0.011 & 7.37 & 5.69 \\
\hline Gross written Premiums Talanx & 26.625 & 4.825 & 18.12 & 5.85 \\
\hline Acquisition expenses Talanx & 5.404 & 1.099 & 20.33 & \\
\hline
\end{tabular}

Table 3. Coefficients and p-value of line trends (source: own study based on Consolidated Financial Statements (Gretl CC))

\begin{tabular}{|c|c|c|c|c|c|}
\hline Dependent variable & Coefficient & $\begin{array}{l}\mathrm{p} \text {-value in a } \\
\text { significance test }\end{array}$ & $\begin{array}{l}\mathrm{p} \text {-value in } \\
\text { White's test }\end{array}$ & $\begin{array}{l}\text { p-value in Dur- } \\
\text { bin-Watson's } \\
\text { test }\end{array}$ & $\begin{array}{l}\mathrm{p} \text {-value in } \\
\text { RESET test }\end{array}$ \\
\hline Gross value - AXA & 0.14 & 0.000 & 0.10 & 0.03 & 0.14 \\
\hline Net value - AXA & 0.039 & 0.000 & 0.08 & 0.08 & 0.35 \\
\hline IT expenses - AXA & 0.047 & 0.060 & 0.48 & 0.54 & 0.51 \\
\hline Gross written premiums - AXA & 1.171 & 0.005 & 0.82 & 0.02 & 0.04 \\
\hline Acquisition costs - AXA & 0.253 & 0.000 & 0.88 & 0.22 & 0.17 \\
\hline Gross value - Zurich & 0.278 & 0.004 & 0.07 & 0.00 & 0.00 \\
\hline \multirow{2}{*}{$\begin{array}{l}\text { Gross value - Zurich (time and } \\
\text { time squared used as regressors) }\end{array}$} & 1.028 & 0.000 & \multirow{2}{*}{0.80} & \multirow{2}{*}{0.00} & \multirow{2}{*}{0.01} \\
\hline & -0.068 & 0.001 & & & \\
\hline \multirow{3}{*}{$\begin{array}{l}\text { Gross value }- \text { Zurich (time, time } \\
\text { squared and time cubed used as } \\
\text { regressors) }\end{array}$} & 2.02 & 0.000 & \multirow{3}{*}{0.44} & \multirow{3}{*}{0.51} & \multirow{3}{*}{0.48} \\
\hline & -0.284 & 0.000 & & & \\
\hline & 0.013 & 0.000 & & & \\
\hline Net value - Zurich & -0.003 & $0.880^{*}$ & 0.07 & 0.00 & 0.00 \\
\hline
\end{tabular}


Continued Table 3

\begin{tabular}{|c|c|c|c|c|c|}
\hline Dependent variable & Coefficient & $\begin{array}{c}\mathrm{p} \text {-value in a } \\
\text { significance test }\end{array}$ & $\begin{array}{l}\text { p-value in } \\
\text { White's test }\end{array}$ & $\begin{array}{l}\text { p-value in Dur- } \\
\text { bin-Watson's } \\
\text { test }\end{array}$ & $\begin{array}{l}\text { p-value in } \\
\text { RESET test }\end{array}$ \\
\hline \multirow{2}{*}{$\begin{array}{l}\text { Net value }- \text { Zurich (time and } \\
\text { time squared used as regres- } \\
\text { sors) }\end{array}$} & 0.211 & 0.001 & \multirow{2}{*}{0.08} & \multirow{2}{*}{0.11} & \multirow{2}{*}{0.51} \\
\hline & -0.019 & 0.001 & & & \\
\hline IT expenses - Zurich & 0.095 & 0.000 & 0.88 & 0.06 & 0.02 \\
\hline $\begin{array}{c}\text { Gross written premiums - } \\
\text { Zurich } \\
\end{array}$ & -0.595 & 0.065 & 0.31 & 0.07 & 0.22 \\
\hline Acquisition costs - Zurich & 0.093 & $0.250^{*}$ & 0.23 & 0.01 & 0.13 \\
\hline \multirow{2}{*}{$\begin{array}{c}\text { Acquisition costs }- \text { Zurich } \\
\text { (time and time squared used as } \\
\text { regressors) }\end{array}$} & 0.723 & 0.283 & \multirow[b]{2}{*}{0.65} & \multirow[b]{2}{*}{0.09} & \multirow[b]{2}{*}{0.10} \\
\hline & -0.057 & 0.043 & & & \\
\hline Gross value $-\mathrm{CNP}$ & 0.026 & 0.000 & 0.10 & 0.04 & 0.17 \\
\hline Net value - CNP & 0.017 & 0.000 & 0.64 & 0.26 & 0.28 \\
\hline $\begin{array}{l}\text { Gross written premiums - } \\
\text { CNP }\end{array}$ & 0.199 & $0.450^{*}$ & 0.30 & 0.02 & 0.41 \\
\hline \multirow{2}{*}{$\begin{array}{l}\text { Gross written premiums - } \\
\text { CNP (time and time squared } \\
\text { used as regressors) }\end{array}$} & -1.072 & $0.352 *$ & \multirow[b]{2}{*}{0.23} & \multirow[b]{2}{*}{0.03} & \multirow[b]{2}{*}{0.52} \\
\hline & 0.116 & $0.265^{*}$ & & & \\
\hline Acquisition costs - CNP & 0.104 & 0.000 & 0.39 & 0.00 & 0.00 \\
\hline \multirow{2}{*}{$\begin{array}{l}\text { Acquisition costs - CNP (time } \\
\text { and time cubed used as regres- } \\
\text { sors) }\end{array}$} & 0.03 & 0.076 & \multirow[b]{2}{*}{0.81} & \multirow{2}{*}{0.20} & \multirow[b]{2}{*}{0.11} \\
\hline & 0.001 & 0.000 & & & \\
\hline Gross value - Talanx & 0.018 & 0.000 & 0.43 & 0.89 & 0.81 \\
\hline Net value - Talan $x$ & 0.002 & $0.109^{*}$ & 0.08 & 0.01 & 0.01 \\
\hline \multirow{2}{*}{$\begin{array}{c}\text { Net value - Talanx (time and } \\
\text { time squered used as regres- } \\
\text { sors) }\end{array}$} & -0.009 & 0.015 & \multirow[b]{2}{*}{0.38} & \multirow[b]{2}{*}{0.27} & \multirow[b]{2}{*}{0.31} \\
\hline & 0.001 & 0.005 & & & \\
\hline $\begin{array}{c}\text { Gross written premiums - } \\
\text { Talanx } \\
\end{array}$ & 0.199 & $0.445^{*}$ & 0.21 & 0.37 & 0.19 \\
\hline Acquisition costs - Talanx & 0.344 & 0.000 & 0.32 & 0.02 & 0.12 \\
\hline Gross value - AXA & 0.14 & 0.000 & 0.10 & 0.03 & 0.14 \\
\hline Net value - AXA & 0.039 & 0.000 & 0.08 & 0.08 & 0.35 \\
\hline IT expenses - AXA & 0.047 & 0.060 & 0.48 & 0.54 & 0.51 \\
\hline $\begin{array}{c}\text { Gross written premiums - } \\
\text { AXA }\end{array}$ & 1.171 & 0.005 & 0.82 & 0.02 & 0.04 \\
\hline Acquisition costs - AXA & 0.253 & 0.000 & 0.88 & 0.22 & 0.17 \\
\hline Gross value - Zurich & 0.278 & 0.004 & 0.07 & 0.00 & 0.00 \\
\hline \multirow{2}{*}{$\begin{array}{c}\text { Gross value }- \text { Zurich (time and } \\
\text { time squared used as } \\
\text { regressors) }\end{array}$} & 1.028 & 0.000 & \multirow[b]{2}{*}{0.80} & \multirow[b]{2}{*}{0.00} & \multirow[b]{2}{*}{0.01} \\
\hline & -0.068 & 0.001 & & & \\
\hline \multirow{3}{*}{$\begin{array}{l}\text { Gross value - Zurich (time, } \\
\text { time squared and time cubed } \\
\text { used as regressors) }\end{array}$} & 2.02 & 0.000 & \multirow{3}{*}{0.44} & \multirow{3}{*}{0.51} & \multirow{3}{*}{0.48} \\
\hline & -0.284 & 0.000 & & & \\
\hline & 0.013 & 0.000 & & & \\
\hline Net value - Zurich & -0.003 & $0.880^{*}$ & 0.07 & 0.00 & 0.00 \\
\hline Net value - Zurich (time and & 0.211 & 0.001 & & & \\
\hline $\begin{array}{l}\text { time squared used as regres- } \\
\text { sors) }\end{array}$ & -0.019 & 0.001 & 0.08 & 0.11 & 0.51 \\
\hline IT expenses - Zurich & 0.095 & 0.000 & 0.88 & 0.06 & 0.02 \\
\hline
\end{tabular}


End of Table 3

\begin{tabular}{|c|c|c|c|c|c|}
\hline Dependent variable & Coefficient & $\begin{array}{l}\mathrm{p} \text {-value in a } \\
\text { significance test }\end{array}$ & $\begin{array}{l}\mathrm{p} \text {-value in } \\
\text { White's test }\end{array}$ & $\begin{array}{l}\text { p-value in Dur- } \\
\text { bin-Watson's } \\
\text { test }\end{array}$ & $\begin{array}{l}\mathrm{p} \text {-value in } \\
\text { RESET test }\end{array}$ \\
\hline $\begin{array}{c}\text { Gross written premiums - } \\
\text { Zurich }\end{array}$ & -0.595 & 0.065 & 0.31 & 0.07 & 0.22 \\
\hline Acquisition costs - Zurich & 0.093 & $0.250^{*}$ & 0.23 & 0.01 & 0.13 \\
\hline \multirow{2}{*}{$\begin{array}{l}\text { Acquisition costs }- \text { Zurich } \\
\text { (time and time squared used as } \\
\text { regressors) }\end{array}$} & 0.723 & 0.283 & \multirow{2}{*}{0.65} & \multirow{2}{*}{0.09} & \multirow{2}{*}{0.10} \\
\hline & -0.057 & 0.043 & & & \\
\hline Gross value $-\mathrm{CNP}$ & 0.026 & 0.000 & 0.10 & 0.04 & 0.17 \\
\hline Net value - CNP & 0.017 & 0.000 & 0.64 & 0.26 & 0.28 \\
\hline $\begin{array}{l}\text { Gross written premiums - } \\
\text { CNP }\end{array}$ & 0.199 & $0.450^{*}$ & 0.30 & 0.02 & 0.41 \\
\hline \multirow{2}{*}{$\begin{array}{l}\text { Gross written premiums - } \\
\text { CNP (time and time squared } \\
\text { used as regressors) }\end{array}$} & -1.072 & $0.352 *$ & \multirow[b]{2}{*}{0.23} & \multirow[b]{2}{*}{0.03} & \multirow[b]{2}{*}{0.52} \\
\hline & 0.116 & $0.265^{*}$ & & & \\
\hline Acquisition costs - CNP & 0.104 & 0.000 & 0.39 & 0.00 & 0.00 \\
\hline \multirow{2}{*}{$\begin{array}{l}\text { Acquisition costs- CNP (time } \\
\text { and time cubed used as } \\
\text { regressors) }\end{array}$} & 0.03 & 0.076 & \multirow[b]{2}{*}{0.81} & \multirow[b]{2}{*}{0.20} & \multirow[b]{2}{*}{0.11} \\
\hline & 0.001 & 0.000 & & & \\
\hline Gross value - Talanx & 0.018 & 0.000 & 0.43 & 0.89 & 0.81 \\
\hline Net value - Talanx & 0.002 & $0.109^{*}$ & 0.08 & 0.01 & 0.01 \\
\hline \multirow{2}{*}{$\begin{array}{c}\text { Net value - Talanx (time and } \\
\text { time squered used as } \\
\text { regressors) }\end{array}$} & -0.009 & 0.015 & \multirow[b]{2}{*}{0.38} & \multirow{2}{*}{0.27} & \multirow[b]{2}{*}{0.31} \\
\hline & 0.001 & 0.005 & & & \\
\hline $\begin{array}{c}\text { Gross written premiums - } \\
\text { Talanx }\end{array}$ & 0.199 & $0.445^{*}$ & 0.21 & 0.37 & 0.19 \\
\hline Acquisition costs - Talanx & 0.344 & 0.000 & 0.32 & 0.02 & 0.12 \\
\hline
\end{tabular}

\section{Conclusions}

Digitalization in insurance companies becomes an important phenomenon. It brings new opportunities for business development. The research study showed the dilemma between theoretical background and the practical realization of digitalization processes in insurance:

- digitalization in insurance becomes to be an important topic in science; there is some ambiguity in the understanding of the definition, structure, and mechanism of digitalization in insurance. Information technologies are commonly accepted as an attribute of digitalization;

- the indicators of IT expenses and software gross value are the only parameters from financial statements that could be used for analysis of digital activity in the insurance company. We showed just a part of the instruments that are currently used in selected insurance groups: information technologies and software.

The empirical verification showed the relationship between selected indicators:

The biggest insurance group in the European Union started spending more money on software and IT comparing 2017 to 2008. It was proved by the results of all the selected companies. Dynamics of such expenses changed basically and doubled. So, we could state that insurance companies become more interested in new technologies and programs.

The research showed a strong positive correlation between software gross value and gross written premiums in the case of AXA Group and Talanx Group - about 0.9, the low correlation for CNP Group (about 0.3) and even negative correlation for Zurich Group $(-0.5)$. It means that there is no general regularity between the raising of gross premium and ICT expenses. There could be other reason for IT investments, or it is also possible that changes in gross premiums have different effects. And decreasing ICT costs is a consequence of a decision that isn't directly connected with insurance inflow.

The analysis of linkage between acquisition costs and software value could be explained by the difference that was mentioned above. The companies with a low positive correlation between gross writing premium and software gross value showed a high positive correlation between acquisition costs and gross value of software. 


\section{References}

AXA. (2019). Publications. Retrieved from https://group.axa.com/en/newsroom/publications

Bennett, N., \& Lemoine, J. (2014). What VUCA really means for you? Harvard Business Review, 92(1-2). https://doi.org/10.1016/j.bushor.2014.01.001

Berry-Stölzle, T., Hoyt, R., \& Wende, S. (2010). Successful business strategies for insurers entering and growing in emerging markets. The Geneva Papers on Risk and Insurance - Issues and Practice, 35(1), 110-128. https://doi.org/10.1057/gpp.2009.35

Bohnert, A., Fritzsche, A., \& Gregor, S. (2019). Digital agendas in the insurance industry: the importance of comprehensive approaches. The Geneva Papers on Risk and Insurance - Issues and Practice, 44, 1-19. https://doi.org/10.1057/s41288-018-0109-0

Brynjolfsson, E., Hitt, L., \& Yang, S. (2002). Intangible assets: computers and organizational capital. Brookings Papers on Economic Activity, 1, 182-198. https://doi.org/10.1353/eca.2002.0003

Cappiello, A. (2018). Technology and the insurance industry. Re-configuring the competitive landscape. Palgrave Pivot, Cham. https://doi.org/10.1007/978-3-319-74712-5_2

CNP Assurance. (2019). Publications. Retrieved from www.cnp.fr/en/The-Group/Publications/Annual-reports

Eling, M., \& Lehmann, M. (2018). The impact of digitalization on the insurance value Chain and the insurability of risks. The Geneva Papers on Risk and Insurance - Issues and Practice, 43(3), 259-296. Retrieved from https://doi.org/10.1057/s41288017-0073-0

Engel, J. D. (1995). Technology in claims management. Risk Management, 42(12), 13.

Essvale Corporation Limited. (2009). Business knowledge for IT in insurance: the complete handbook for IT professionals. London: Lighting Source Ltd.

Fichnam, R., Dos Santos, B., \& Zheng, Z. (2014). Digital Innovation as a Fundamental and Powerful Concept in the Information Systems Curriculum. MIS Quarterly, 38(2), 329-353. https://doi.org/10.25300/MISQ/2014/38.2.01

Forman, C., \& Gron, A. (2011). Vertical integration and information technology investment in the insurance industry. The Journal of Law, Economics, and Organization, 27(1), 180-218. https://doi.org/10.1093/jleo/ewp023

Francalanci, C., \& Galal, H. (1998). Aligning IT investments and workforce composition: the impact of diversification in life insurance companies. European Journal of Information Systems, 7(3), 175-184. https://doi.org/10.1057/palgrave.ejis.3000301

Gatzert, N. (2019). An analysis of transaction costs in participating life insurance under mean-variance preferences. Insurance: Mathematics and Economics, 85, 185-197. https://doi.org/10.1016/j.insmatheco.2019.01.003

Harris, S., \& J. Katz, J. (1991). Firm size and information technology investment intensity of life insurers. MIS Quarterly, 15(3), 333-352. https://doi.org/10.2307/249645

Heeks, R. (2017). Information and communication technology for development. London: Routledge. https://doi.org/10.4324/9781315652603

International Accounting Standards. (2014). Intangible assets. Retrieved from https://www.zurich.com/en/investor-relations/results-and-reports

International Association of Insurance Supervisors. (2018). Issues paper on the increasing use of digital technology in insurance and its potential impact on consumer outcomes. Retrieved from https://www.iaisweb.org/page/supervisory-material/issuespapers/file/77816/issues-paper-on-increasing-digitalisation-in-insurance-and-its-potential-impact-on-consumer-outcomes

Kramarić, T., Bach, M., Dumičić, K., Žmuk, B., \& Žaja, M. (2018). An exploratory study of insurance companies in selected posttransition countries: a non-hierarchical cluster analysis. Central European Journal of Operations Research, 26(3), $783-807$. https://doi.org/10.1007/s10100-017-0514-7

Manning, R., Stephenson, M., \& Todd, J. (1985). Information technology in the insurance industry: a forecast of utilization and impact. The Journal of Risk and Insurance, 52(4), 711-722. https://doi.org/10.2307/252316

Mansell, R., Avgerou, C., Silverstone, R., \& Quah, D. (2007). The Oxford handbook of information and communication technologies. Oxford: Oxford University Press. https://doi.org/10.1093/oxfordhb/9780199548798.001.0001

Marinč, M. (2013). Banks and information technology: marketability vs. relationships. Electron Commerce Research, 13(1), 71101. https://doi.org/10.1007/s10660-013-9107-2

Mithas, S., Tafti, A., Bardhan, I., \& Goh, J. (2012). Information technology and firm profitability: mechanisms and empirical evidence. MIS Quarterly, 36(1), 205-224. https://doi.org/10.2307/41410414

Mizgier, K., Kocsis, O., \& Wagner, S. (2018). Zurich insurance uses data analytics to leverage the BI insurance proposition. INFORMS Journal on Applied Analytics, 48(2), 94-107. https://doi.org/10.1287/inte.2017.0928

Navarrete, C. J., \& Pick, J. B. (2002). Information technology expenditure and industry performance: the case of the Mexican banking industry. Journal of Global Information Technology Management, 5(2), 7-28. https://doi.org/10.1080/1097198X.2002.10856323

Nicoletti, B. (2016). Digital insurance: business innovation in the Post-crisis era. UK: Palgrave Macmillan. https://doi.org/10.1057/9781137553270

Schmidt, R., Möhring, M., Bär, F., \& Zimmermann A. (2017). The impact of digitization on information system design - an explorative case study of digitization in the insurance business. In W. Abramowicz (Ed.), Business information systems workshops. BIS 2017. Lecture notes in business information processing (pp. 137-149). Cham: Springer.

Shin, N. (2001). The impact of information technology on financial performance: the importance of strategic choice. European Journal of Information Systems, 10(4), 227-236. https://doi.org/10.1057/palgrave.ejis.3000409

Sidorova, A., Torres, R., \& Al Beayeyz, A. (2015). The role of information technology in business process management. In J. vom Brocke \& M. Rosemann (Eds.), Handbook on business process management 1. International handbooks on information systems (pp. 421-444). Berlin, Heidelberg: Springer. https://doi.org/10.1007/978-3-642-45100-3_18

Statista. (2019a). Technology \& telecommunications. Retrieved from https://www.statista.com/ markets/418/technology-telecommunications/ 
Statista. (2019b). InsurTech. Retrieved from https://www.statista.com/topics/4116/insurtech/

Stöckli, E., Uebernickel, F., \& Brenner, W. (2016). Digitalization in the insurance industry. Themes and decisions thatmatter: insights from a multiple-case study in Germany and Switzerland. In Working Paper Series on Research in Information Systems Management and Business Innovation. St. Gellen: University of St. Gallen.

Stoeckli, E., Dremel, C., \& Uebernickel, F. (2018). Exploring characteristics and transformational capabilities of InsurTech innovations to understand insurance value creation in a digital world. Electronic Markets, 28(3), 287-305. https://doi.org/10.1007/s12525-018-0304-7

Strålin, T., Gnanasambandam, C., Andén, P., Comella-Dorda, S., \& Burkacky, O. (2016). Software development handbook. Transforming for the digital age. McKinsey \& Company, Inc. Retrieved from https://www.mckinsey.com/industries/high-tech/ourinsights/software-development-handbook-transforming-for-the-digital-age

Sumathi, S., \& Sivanandam, S. N. (2006). Introduction to data mining and its applications. Studies in computational intelligence. Verlag Berlin: Springer. https://doi.org/10.1007/978-3-540-34351-6

Talanx. (2019). Publication and presentation. Retrieved from https://www.talanx.com/investor-relations/presentations-andevents/disclosure

Tien, J., \& Yang, S. (2014). The Determinants of life insurer's growth for a developing insurance market: domestic vs foreign insurance firms. The Geneva Papers on Risk and Insurance - Issues and Practice, 39(1), 1-24. https://doi.org/10.1057/gpp.2013.6

Trigo-Gamarra, L., \& Growitsch, G. (2010). Comparing single and multichannel distribution strategies in the german life insurance market: an analysis of cost and profit efficiency. Schmalenbach Business Review, 62(4), 401-417. https://doi.org/10.1007/BF03396813

Vogelsang, M. (2010). Digitalization in open economies, contributions to economics. Berlin, Heidelberg: Springer-Verlag. https://doi.org/10.1007/978-3-7908-2392-9

Weingarth, J., Hagenschulte, J., Schmidt, N., \& Balser, M. (2019). Building a digitally enabled future: an insurance industry case study on digitalization. In N. Urbach \& M. Röglinger (Eds.), Digitalization cases. Management for professionals (pp. 249269). Germany: Springer. https://doi.org/10.1007/978-3-319-95273-4_13

Wiesböc, F., Li, L., Matt, C., Hess, T., \& Richter, A. (2017). How management in the German insurance industry can handle digital transformation. In Management report. Munich: Munich School of Management.

Wooldridge, J. M. (2012). Introductory econometrics. A modern approach. Michigan: Cengage Learning.

Zurich Group. (2019). Financial results and reports. Retrieved from https://www.zurich.com/en/investor-relations/results-and-reports 